\title{
ETHNOMATHEMATICS AND THE PURSUIT OF PEACE AND SOCIAL JUSTICEI
}

\author{
ETNOMATEMÁTICA E A BUSCA PELA PAZ E JUSTIÇA SOCIAL
}

\section{ETNOMATEMÁTICAS Y LA BÚSQUEDA DE PAZ Y JUSTICIA SOCIAL}

Ubiratan D'Ambrosio ${ }^{1}$

\begin{abstract}
Currently, issues affecting society such as national security, personal security, economics, social and environmental disruption, relations among nations, relations among social classes, people's welfare, the preservation of natural and cultural resources, and many others can be synthesized as Peace in its several dimensions: Inner Peace, Social Peace, Environmental Peace, and Military Peace. These four dimensions are intimately related. Social Justice naturally leads to Social Peace. Although, as I said, the four dimensions of Peace are intimately related, in this essay I will focus my reflection on Social Justice and how can Ethnomathematics as a program contribute to it.
\end{abstract}

KEYWORDS: Ethnomathematics. Mathematics Education. Peace. Political Dimensions. Social Justice.

\section{RESUMO}

Atualmente, as questões que afetam a sociedade hoje em dia como a segurança nacional, a segurança pessoal, a economia, as perturbações sociais e ambientais, as relações entre as nações, as relações entre as classes sociais, o bem-estar das pessoas, a preservação dos recursos naturais e culturais e muitos outros podem ser sintetizados como Paz em suas várias dimensões: Paz Interior, Paz Social, Paz Ambiental e Paz Militar. Essas quatro dimensões estão intimamente relacionadas. A Justiça Social conduz naturalmente à Paz Social. Embora, como eu disse, as quatro dimensões da Paz estejam intimamente relacionadas, neste ensaio vou focar a minha reflexão sobre a Justiça Social e como a etnomatemática como um programa pode contribuir para isso.

PALAVRAS-CHAVE: Etnomatemática. Educação Matemática. Paz. Dimensões Políticas. Justiça Social.

\section{RESUMEN}

Actualmente, questiones que afectan la sociedad contemporánea, como la seguridad nacional, la seguridad personal, la economía, los trastornos sociales y ambientales, las relaciones entre naciones, las relaciones entre clases sociales, el estado de bienestar, la preservación de los recursos naturales y culturales, y muchas otras más, pueden ser sintetizados como Paz en sus distintas dimensiones: Paz Interior, Paz Social, Paz Ambiental y Paz Militar. Estas cuatro dimensiones están íntimamente relacionadas. La justicia social conduce naturalmente a la Paz Social. A pesar de que, como dije, estas cuatro dimensiones de la Paz están íntimamente relacionadas, en este ensayo mi reflexión está centrada en la Justicia Social y cómo la Etnomatemática puede contribuir a ella.

PALABRAS CLAVE: Etnomatemática. Educación Matemática. Paz. Dimensión Política. Justicia Social.

\footnotetext{
${ }^{1}$ Doutor em Matemática - Universidade de São Paulo (USP) - São Paulo, SP - Brasil. Professor Emérito da Universidade Estadual de Campinas (UNICAMP) - Campinas, São Paulo - Brasil. Docente permanente do Programa de Pós-Graduação em Educação Matemática da Universidade Anhanguera de São Paulo (UNIAN) São Paulo, SP - Brasil. E-mail: ubi@usp.br

Received on: 25/02/2017 - Accepted on: 31/05/2017

(C) ETD-Educação Temática Digital Campinas, SP $\quad$ v.19 $\quad$ n.3 $\quad$ p. 653-666 jul./set. 2017
}




\section{INTRODUCTORY REMARKS}

I claim that the major goals of Education are to promote:

- Creativity, helping people to fulfill their potential and raise to the highest of their capability, but being careful not to promote docile citizens. We do not want our students to become citizens who merely obey and accept rules and codes that violate human dignity.

- Citizenship, transmitting values and showing rights and responsibilities in society, but being careful not to promote irresponsible creativity. We do not want our students to become bright scientists creating new weaponry and instruments of oppression and inequity.

These two major goals guide all my reflections and proposals. Curriculum is usually organized in three strands: objectives, contents, and methods and it is the strategy to achieve these goals.

The big challenge faced by educators is in carrying out curriculum that creates tension between the "present", of the "old", where parents and teachers conveying values established in the "past", and the "new", children and students, with creativity pointing to the "future". Present societal values were established in the past and are essential in the concept of citizenship, while innovation and improvement of these values results in a sense of creativity, which is essential for the future.

Hopefully, this encounter can create harmony and not more conflict. There are multiple challenges: changes in the environment, in demography and urban conditions, in labor, in transportation and, above all, in the technologies of information and communication. All these factors must be considered in trying to fulfill the major goals of education.

\section{THE RESPONSIBILITY OF MATHEMATICIANS AND MATHEMATICS EDUCATORS}

It is widely recognized that all the issues affecting society are universal, and it is common to blame the technological, industrial, military, economic, and political complexes as responsible for the growing crises threatening humanity. Yet, in truth, "survival with dignity is the most universal problem facing mankind".
(C) ETD- Educação Temática Digital
Campinas, SP
v.19
n. 3
p. $653-666$
jul./set. 2017 
Mathematics, mathematicians, and mathematics educators are deeply involved with all these issues. We learn, through history, that the technological, industrial, military, economic and political complexes have all grew and developed thanks to many mathematical instruments. And at the same time, that mathematics has relied upon these complexes for the material and financial base for its continuing progress. It is also widely recognized that "mathematics is the most universal mode of thought".

And so it is that I propose a major question: Are the most universal problems facing humanity and the most universal modes of thought, conflicting or are they complementary? I am absolutely convinced that mathematicians and mathematics educators must be equally concerned with these two universals.

It is necessary that mathematicians and mathematics educators, indeed all scientists and science educators must look very deeply at the relations between these two universals. Scholars and educators in general, in all scientific and humanistic disciplines, particularly mathematicians and mathematics educators, must accept, as a priority, the pursuit of a civilization with dignity for all, in which inequity, arrogance and bigotry have no place.

Regrettably, a barrier has appeared and obfuscates the practices of mathematics educators, as well as mathematics researchers. They continue to give priority to their discipline and to their specialties. Their academic preparation was very different in relation to their sociocultural and cognitive environments. Metaphorically, they preserve the umbilical cord with their academic preparation. The priority is to publish their research in the best journals, to be recognized by their peers.

It is especially discouraging that teachers are tied and subordinated to obsolete content and methods with an objective to prepare students to pass a variety of standardized tests which are imposed on them by authorities and conservative educators, parents, and traditions. Sameness prevails! To reverse this situation, it is necessary for the mathematics educators, as well as educators in general, the encouragement of practicing a creative insubordination (D'AMBROSIO; LOPES, 2015).

Although with a somewhat different focus, discussing individualism in research activities, the late John M. Ziman described, in a provocative essay, the essence of a familiar attitude:

(C) ETD-Educação Temática Digital Campinas, SP $\quad$ v.19 $\quad$ n.3 $\quad$ p.653-666 jul./set. 2017 
To a remarkable degree, the scientist is represented as studying the natural world as if alone in it, served only by mindless assistants who might as well be replaced by machines. Scientific theories are presented as systems of thought conjured up and tested by that same individual in a further series of single-headed operations. Research results are formulated and treated philosophically as the independent findings of lone explorers, each reporting the evidence of their own eyes and their rational inferences concerning the hidden mechanisms by which these personal percepts might be generated (ZIMAN, 2006, p. 17).

The Program Ethnomathematics is a response of mathematicians and mathematics educators to face this responsibility, offering venues for "Peace", in all its four dimensions:

- Inner peace.

- Social peace.

- Environmental peace.

- Military peace.

The Program Ethnomathematics, which will be discussed later in this paper, is a research program on mathematics that is related to history and education. It begins with a reflection on the nature of mathematics, basically, asking how mathematics is created and how different mathematical creativity is from other forms of creativity. In facing these questions, there is a need for a complete and structured view of the role of mathematics in building up our civilization, hence a look into the history and geography of human behavior.

History is usually regarded and taught as a chronological narrative of events, focused in the narrow geographic limits of a few civilizations, which have been successful in a short span of time. The course of the history of humanity cannot be separated from the sociocultural history of civilization, which has developed in close and increasing interdependence with the natural history of the planet Earth.

There are indications that the planet Earth was formed about 4.5 billion years ago. Its geological history is divided in eras, the Precambrian, Paleozoic, Mesozoic, and Cenozoic. The lengths of these eras are often measured by the term mya, which represents millions of years ago. The Cenozoic Era, 65.5 mya, is also called the Age of Mammals and the Age of Birds. In the advanced stages of this era, the first recognizable humans came into existence.

Now, a group of geologists and other scientists propose to define a new geological epoch that is marked by climatic and environmental changes caused by humans, which they call the Age of Man or Anthropocene that began about 60,000 years ago, when the species homo neanderthalensis became extinct and the species homo sapiens flourished. The Anthropocene intensified about 11,500 years ago, with the emergence of agriculture.
(C) ETD- Educação Temática Digital
Campinas, SP
v.19
n.3
p. $653-666$
jul./set. 2017 
So it is that we have come to question what did our species do to the planet? The threat of extinction is real, as the emeritus mathematician Mikhail L. Gromov, laureate in 2009 with an Abel Prize, the equivalent of the Nobel Prize for mathematicians, alerts. In an interview, Gromov says:

Earth will run out of the basic resources, and we cannot predict what will happen after that. We will run out of water, air, soil, rare metals, not to mention oil. Everything will essentially come to an end within fifty years. What will happen after that? I am scared. It may be okay if we find solutions, but if we don't then everything may come to an end very quickly. Mathematics may help to solve the problem, but if we are not successful, there will not be any mathematics left, I am afraid! (Raussen \& Skau, 2010, p. 395).

The suggestion posed by Gromov is that mathematics offers the instruments to face this threat, but it asks for a deep reflection about the nature of mathematics and of mathematics education. To face this real threat to the continuation of civilization we need innovation in mathematics, broadening their foundations, their contents, and their methods. What we have been doing in schools and academia, even in research, is to convey and to improve, with more details, results from the past, useful and important sometimes centuries ago, but of questionable value for today's challenges.

It is impossible to disregard ideas, theories, concepts, and methods from the past, particularly, in mathematics. But, they may lose their interest, became obsolete and must be replaced by new ideas. Of course, there is a permanent and very important presence of these ideas, theories, concepts and methods as historical sources. A vision and perception of the past is very important in guiding our reflections in the present and to support innovation aiming at the future. But it is different than thinking, living and acting as in the past. As an example, I mention paper and pencil arithmetic, now replaced by calculators.

As the eminent mathematician David Hilbert (1862-1943) said in his celebrated conference in the International Congress of Mathematicians, in Paris, in 1900:

History teaches the continuity of the development of science. We know that every age has its own problems, which the following age either solves or casts aside as profitless and replaces by new ones. If we would obtain an idea of the probable development of mathematical knowledge in the immediate future, we must let the unsettled questions pass before our minds and look over the problems which the science of today sets and whose solution we expect from the future (HILBERT, 1902, p. 437).

I proceed with these reflections.

(C) ETD-Educação Temática Digital Campinas, SP $\quad$ v.19 n.3 $\quad$ p. 653-666 jul./set. 2017 


\section{THE POLITICAL DIMENSIONS OF MATHEMATICS EDUCATION}

The discussion on the objectives of mathematics education or, in other words, Why teach mathematics or Why do we teach mathematics? is regarded as the political dimension of education, but very rarely do we see mathematics content and methodology examined with respect to this dimension. Indeed, some mathematicians and educators claim that content and methods in mathematics have nothing to do with the political dimension of education.

Since mathematics is, as discussed above in this paper, a universal imprint of Western thought, it is naïve not to look into a possible role of mathematics in framing a state of mind that violates the four dimensions of Peace. As argued above, it appears to me that right now, our major responsibility, as mathematicians and mathematics educators, is to offer venues for peace (D'AMBROSIO, 1998).

There is an expectation about our role, as mathematicians and mathematics educators, in the pursuit of Peace. Anthony Judge, former Director of Communications and Research of the Union of International Associations, expressed how mathematicians are seen by other scientists:

\footnotetext{
Mathematicians, having lent the full support of their discipline to the weapons industry supplying the missile delivery systems, would claim that their subtlest thinking is way beyond the comprehension of those seated around a negotiating table. They have however failed to tackle the challenge of the packing and unpacking of complexity to render it comprehensible without loss of relationships vital to more complex patterns. As with the protagonists in any conflict, they would deny all responsibility for such failures and the manner in which these have reinforced unsustainably simplistic solutions leading to further massacres (JUDGE, 2000, online).
}

I believe our research must go in the opposite direction. I see that our role as educators as complementary actions in our classrooms and in the advancement of our discipline. This is true for every field of knowledge. To fulfill our commitments to humanity, we have to make much better use of these instruments and to master them. But, we also need to have a critical view of their potentialities and of the risk involved in misusing them. We cannot avoid alerting children that the instruments we are offering them are greatly at risk for being used to increase inequity, destruction and even war. I claim that this should be our major professional commitment.

(C) ETD-Educação Temática Digital Campinas, SP v.19 n.3 $\quad$ p. 653-666 jul./set. 2017 
It is impossible to deny that mathematics provides an important instrument for social analyses. Western civilization entirely relies on data control and management. As said by mathematics educator Lynn Steen, "The world of the twenty-first century is a world awash in numbers" (STEEN, 2001, p. 1). Social analysis is practically impossible without an understanding of basic quantitative mathematics. But, quantitative mathematics is not enough. Indeed, it may give false impressions without qualitative support and interpretation.

Since the emergence of Modern Science, enormous emphasis has been placed on the rational dimension of man. Recently, the multiple intelligences: especially emotional intelligence, spiritual intelligence, and numerous approaches to cognition, including new developments in artificial intelligence and neuro-cognition must be taken into account. This goes in the other direction of emphasis given to the quantitative, embodied in skill and drilling, as defended in some circles of mathematicians and mathematics educators.

I argue against an excessive emphasis on the quantitative, which may be detrimental to very important qualitative aspects. A response to these considerations is my proposal of a new curriculum based in the trivium with three components: literacy, matheracy, and technoracy (D’AMBROSIO, 1999a).

Literacy conveys the communicative instruments, which includes what has been called quantitative literacy or numeracy, but much more. It is the capability of processing information, such as the use of written and spoken language, of signs and gestures, of codes and numbers. Clearly, reading and writing have new meanings now. Reading also includes the competency of interpreting graphs and tables and of other ways of informing the individual, even the condensed language of codes. These competencies have much more to do with screens and buttons than with pencil and paper. There is no way to reverse this trend.

Matheracy is the capability of inferring, proposing hypotheses, and drawing conclusions from data. It is a first step toward an intellectual posture, which is almost completely absent in our school systems. Regrettably, even conceding that problem solving, modeling, and projects can be seen in some mathematics classrooms, the main importance is usually given to the quantitative solutions, which are essentially manipulation of numbers and operations. Matheracy is closer to the way mathematics was present both in classical Greece and in Indigenous cultures. The concern was not with counting and measuring, but with divination and philosophy, with symbolic and abstract thinking. Matheracy leads to a
(C) ETD-Educação Temática Digital
Campinas, SP
v.19
n.3
p. $653-666$
jul./set. 2017 
deeper reflection about humanity and society and should not be restricted to the elite, as it has been in the past, but it should enter school curricula.

Technoracy is the critical familiarity with technology. Of course, the operative aspects of it are, in most cases, inaccessible to the lay individual. But, the basic ideas behind technological devices, their possibilities and dangers, the morality supporting the use of technology, are essential issues to be raised among children at a very early age of schooling. The Internet is an enormous progress; learning to use web search engines, collaborativecreated encyclopedias, application software and social networking websites must be incorporated into daily usage. These facilities urge for technoracy as a critical analysis of their possibilities and misuses. History shows that ethics and values are intimately related to the technological progress.

\section{THE ETHICAL DIMENSION OF MATHEMATICS EDUCATION}

The essence of ethics is the recognition that every human being has the entitlement to the same expectations, rights, and benefits of progress. As educators, we must recognize that the classroom is in reality a small community of human beings, were we are put together to learn, to respect, and share the opportunity of achieving our expectations and rights. We have to support this with respect, solidarity and cooperation for all. This is a major factor for quality of life and dignity for all. It is impossible to accept the exclusion of large sectors of the population of the world, both in developed and undeveloped nations.

The perverse concept of civilization practiced in the past and still practiced nowadays, such as conquest, colonialism, slavery and even genocide, requires our critical attention. There is no point to blame one or another and it is hopeless to redo or to redeem the cultural damage caused. The damage is irreversible. The only real possibility is to explore extant cultural traces and to reconstruct the structural roots of a culture, particularly our myths, language and daily practices. To understand what happened in the past, dominated by arrogance and bigotry, is a first step to move into the future.

Mathematics has everything to do with the state of the world. A new world order is an urgent need. To accept inequity, arrogance, and bigotry is irrational and may lead to disaster. Our hopes for the future depend on critically learning the lessons from the past. We have to look into history and epistemology with a broader view. The denial and exclusion of peripheral cultures so common in the colonial process, still prevails in modern society.

(C) ETD-Educação Temática Digital Campinas, SP $\quad$ v.19 $\quad$ n.3 $\quad$ p.653-666 jul./set. 2017 
Currently, the denial of knowledge that affects many populations, particularly, children, is of the same nature and causes deliberate harm to society. A serious harm is that large sectors of the population do not have access to full citizenship and even to the basic needs for survival. This is the situation in most of the world, even in the most developed and richest of nations.

New possibilities of non-traumatic access to knowledge may be obtained with respectful recognition of how major sectors of society, the so-called invisible society, deal with their everyday needs and practices. To give voice to the members of our invisible societies, also called, the common people, is absolute priority in education in all levels, particularly, in teacher training.

In a very interesting book, historian Robert Knapp has discussed the ways in which the common people in Ancient Rome, every man, woman and child, the poor and the rulers, the merchants and the artisans, the teachers, and the artists and entertainers, the pious and the impious, the slaves and the freedmen, the soldiers, the prostitutes, the gladiators, the bandits, the pirates, and practically everyone whose names are not recorded, dealt with every-day life (KNAPP, 2011). This stratification and complexity of society has been present ever since humans gathered into groups and created society. By and large, they constitute an invisible society of doing and knowing of unique and creative ways of survival. This has formed one of the main concerns in my research.

Challenging problems that affect daily life lead to unique problem-solving experiences by people as they constructed mathematical content, making sense of procedures and ideas that were simply ad hoc practices and rules. Reflecting on the personal learning experiences, particularly, with teachers working with students from different natural and sociocultural environments, is essential to coming to reflect on the nature of mathematical thinking and on our teaching of mathematics. The pedagogical effect of this approach is helping teachers to reflect on how our students make sense of mathematics and how to create experiences that afford children an occasion for sensemaking. This is a major pedagogical objective of the Program ethnomathematics.

\section{THE PROGRAM ETHNOMATHEMATICS}

The Program Ethnomathematics is a response to the responsability that mathematicians and mathematics educators have in facing the serious educational failures
(C) ETD- Educação Temática Digital
Campinas, SP
v.19
n.3
p. $653-666$
jul./set. 2017 
and it offers a possibility of implementing new curricular options for school systems in order to enhance creativity.

The Program Ethnomathematics rejects inequity, arrogance, and bigotry, and gives special attention to the redemption of people that have been, for a long time, subordinated, giving priority to the empowerment of excluded sectors of societies. It contributes towards restoring cultural dignity and offers intellectual tools towards initiating the full exercise of citizenship for all. By reinforcing cultural self-respect, it offers a broad view of humanity. It is a system of knowledge that offers the possibility of a more favorable and harmonious relation between humans and between humans and nature (D'AMBROSIO, 1999b).

The Program Ethnomathematics offers the possibility of harmonious relations in human behavior and between humans and nature, since it has, intrinsic to it, the ethics of diversity:

- Respect for the other (which is different).

- Solidarity with the other (which is different).

- Cooperation with the other (which is different).

I will now rapidly elaborate on ethnomathematics as a research program, which has obvious pedagogical implications. An important question frequently asked is related to the understanding of ethnomathematics as a research or as a practice. There is no dichotomy between research and practice, as I will try to show it in this text.

I base my research on the analyses of the established forms of knowledge, such as coming from our myths and religions, arts and techniques, sciences and mathematics and also the behavior of people in different natural and socio-cultural environments. It is fundamental to recognize the contributions of every form of knowledge, of many cultures and of the dynamics of cultural encounters to understand how mathematical ideas are generated and how they have evolved through the History of Humanity.

I have come to understand culture in its widest form, it is that which includes the emergence of myths and cults, language, nourishment and shelter, healing practices and how they were structured as religions, philosophy, medicine, music, arts and techniques, the sciences and mathematics. This has its roots in the mergence of the species, going back to the our Paleolithic roots, as was carefully researched by Manoel de Campos Almeida (in press).

(C) ETD-Educação Temática Digital $\quad$ Campinas, SP $\quad$ v.19 $\quad$ n.3 $\quad$ p.653-666 $\quad$ jul./set. 2017 
This research must be transcultural and transdisciplinarian. The encounters of cultures are examined in its widest form to permit exploration of more indirect interactions and influences and to permit examination of subjects on a comparative basis. Basically, any investigation in ethnomathematics starts with three basic questions:

1. How are ad hoc practices and solution of problems developed into methods?

2. How are methods developed into theories?

3. How are theories developed into scientific invention?

The Program Ethnomathematics was initially inspired by the recognition that ideas and ways of doing and knowing are contextualized in the natural and sociocultural environments. I initially obtained an insight into this general approach while visiting other cultural environments during my work in Africa and in practically all the countries of continental America and the Caribbean, in the Pacific, Europe, and the Near, Middle, and Far East. These extensive travels opened my views to Cultural Anthropology. This led me to work with different cultural environments and, as an ethnographer, to describe the mathematical ideas and practices of other cultures.

This is a common style of doing ethnomathematics, which is absolutely necessary. These diverse cultural environments include not only Indigenous populations, but labour and artisan groups, communities in urban environments and in the outlying regions, farms, and professional groups. These groups develop their own procedures, have specific jargon and theorize their own practices, which have developed into methods and paved the way to the new and creative inventions.

In this context, it is important to recognize the special role of technology in the human species and the implications of this for Science and Mathematics. Thus, the History of Science and Technology and, of course, the History of Mathematics, are basic to research in ethnomathematics (D'AMBROSIO, 2004).

The History of Mathematics privileges the codes and techniques developed, organized and formalized in a specific style in academies emerging from the Mediterranean Basin, which later expanded to Northern Europe and to other parts of the World. This academic discipline, nowadays simply called mathematics, is practiced and constitutes the dominant component of school curricula in the entire World. My research questions this privileged view that dominates current History of Mathematics.

(C) ETD-Educação Temática Digital Campinas, SP $\quad$ v.19 $\quad$ n.3 $\quad$ p.653-666 jul./set. 2017 
It is impossible not to recognize that the codes and techniques developed as strategies to express reflections on space and time, such as measuring, quantifying, inferring, and also the emergence of abstract thinking in non-Mediterranean natural and sociocultural environments, many which were completely different to those coming into contact with them. The perception of space and time, which is the basis to generate measuring and quantifying, are a natural response to natural environment.

It is impossible to deny that space in the Arctic tundra is perceived differently from space in the Mediterranean region. The Arctic days and nights alternate in six month cycles, completely different to the patterns and seasonal difference found in the Mediterranean Basin. Hence, the concepts of measuring and quantifying, which originated in the alternation of days and nights must be different. Every region of the World has its proper perception of time. The same is true for space.

The use of the word ethnomathematics is the result of an etymological exercise, as I have extensively explained in many of my papers. I looked for Greek roots to express the ways, the arts and the techniques developed by the humans in specific natural and sociocultural environments to understand, to explain, to deal with daily needs and to satisfy will.

I found three Greek roots that approximately express these meaning: techné (or tics) meaning the ways, arts and techniques developed by the humans; ethno meaning specific natural and socio-cultural environments; mathema meaning to understand, to explain, to deal with daily needs and will (D'AMBROSIO, 1993).

Thus, I composed the expression tics of mathema in distinct ethnos. Instead of using the expression tics + mathema + ethno, I decided to use the word ethnomathematics. Although this same word had been used before, mainly by ethnographers, the way I conceived it, as a shortening of the phrase tics of mathema is distinct ethnos, is original.

But, attention! My use of the word ethnomathematics cannot be confused with ethno + mathematics and even less with ethnic mathematics, as it is used by ethnographers, anthropologists, and even mathematics educators who are concerned with cultural issues. Ethnomathematics, the way I use it, is not an extension of the word mathematics, which is simply the study of quantities, forms and figures, and the relations among them. To avoid these common misunderstandings, I insist in using the term Program Ethnomathematics,

(C) ETD-Educação Temática Digital Campinas, SP $\quad$ v.19 $\quad$ n.3 $\quad$ p.653-666 jul./set. 2017 
which emphasizes my concept and the fact that this is a dynamic program, without a final structure.

The dynamics of the Program Ethnomathematics reflects the dynamics of cultures. Its research methodology offers the possibility of understanding and explaining systems of knowledge, not only of mathematical and scientific nature, but also of practices, such as religions and cults, cooking and dress, sports and dance, and the various professional abilities and practices. Indeed, in my research I look into all the abilities, practices and theoretical reflections of humanity shared as common to many individuals and recognized as communal behaviors.

\section{IN CONCLUSION}

Ethnomathematics practices in school favor respect, solidarity, and cooperation with the others, which is undeniably different. Ethnomathematics is, thus, associated with the pursuit of PEACE. The main goal of Ethnomathematics is to build up a civilization free of truculence, arrogance, intolerance, discrimination, inequity, bigotry, and hatred.

\section{REFERENCES}

ALMEIDA, Manoel de Campos. A matemática na idade da pedra, filosofia, epistemologia, neurofisiologia e pré-história da matemática. São Paulo, SP: Livraria da Física (in press).

D'AMBROSIO, Ubiratan. Etnomatemática: um programa. A Educação Matemática em Revista, v.1, n. 1, p. 5-11, 193.

D'AMBROSIO, Ubiratan. Mathematics and peace: our responsibilities. ZDM, v. 30, n. 3, p. 6773, 1998.

D'AMBROSIO, Ubiratan. Literacy, matheracy, and technoracy: a trivium for today.

Mathematical Thinking and Learning, v. 1, n. 2, p. 131-153, 1999a.

D'AMBROSIO, Ubiratan. Ethnomathematics and its first international congress. ZDM, v. 31, n. 2, p. 50-53,1999b.

D'AMBROSIO, Ubiratan. Ethnomathematics and its place in the history and pedagogy of mathematics. In: CARPENTER, Thomas P., DOSSEY, John A.; KOEHLER, Julie L. (Ed.). Classics

(C) ETD-Educação Temática Digital Campinas, SP $\quad$ v.19 $\quad$ n.3 $\quad$ p.653-666 jul./set. 2017 
in mathematics education research. Reston, VA: National Council of Teachers of Mathematics, 2004. p. 194-199.

D’AMBROSIO, Beatriz Silva; LOPES, Celi Espasandin (Ed.). Creative insubordination in Brazilian mathematics education research. Raleigh NC: Lulu, 2015.

HILBERT, David. Lecture delivered before the International Congress of Mathematicians at Paris in 1900. Bulletin of the American Mathematical Society, p. 437-479, 1902.

JUDGE, Anthony. And when the bombing stops: territorial conflict as a challenge to mathematicians. Laetus in Praesens, 2000. Retrieved from:

http://www.uia.org/uiadocs/mathbom.htm. Accessed on February 11, 2017.

KNAPP, Robert. Invisible romans. Cambridge, MA: Harvard Univ., 2011.

RAUSSEN, Martin; SKAU, Christian. Interview to Mikhail Gromov. Notices of the AMS, v. 57, n. 3, p. 391-409, 2010.

STEEN, Lynn Arthur. Mathematics and democracy: the case for quantitative literacy. Princeton, NJ: National Council on Education and the Disciplines, 2001.

ZIMAN, John. No man is an island. Journal of Consciousness Studies, v. 13, n. 5, p. 17-42, 2006.

'The grammatical and editorial revisions of this article were made by Daniel Clark Orey and Milton Rosa (UFOP). 